\title{
Quando educação e comunicação se encontram no universo coletivo
}

DOI: $10.1590 / 1809-58442018212$

\section{Arquimedes Pessoni ${ }^{1}$}

http://orcid.org/0000-0003-1050-3405

${ }_{1}^{1}$ (Universidade Municipal de São Caetano do Sul, Pró-Reitoria de Pós-Graduação e Pesquisa, Programa de Mestrado Profissional de Inovação em Comunicação de Interesse Público, São Caetano do Sul - SP, Brasil)

TARGINO, M. das G.; SILVA, E. M. P.; SANTOS, M. F. P. dos. (Orgs.). Alfabetização e Letramento: múltiplas perspectivas. Teresina: EDUFPI, 2017.

Pode causar estranheza encontrar em uma revista de comunicação a resenha de uma publicação que remeta à educação. O segredo reside após os dois pontos do título do livro “Alfabetização e Letramento: múltiplas perspectivas”. Sim, múltiplas e, entre as que recheiam os onze capítulos desta edição organizada por Maria das Graças Targino, Evana Mairy Pereira Silva e Maria Fátima Paula dos Santos está a comunicação.

Já na orelha do livro, uma das organizadoras, a

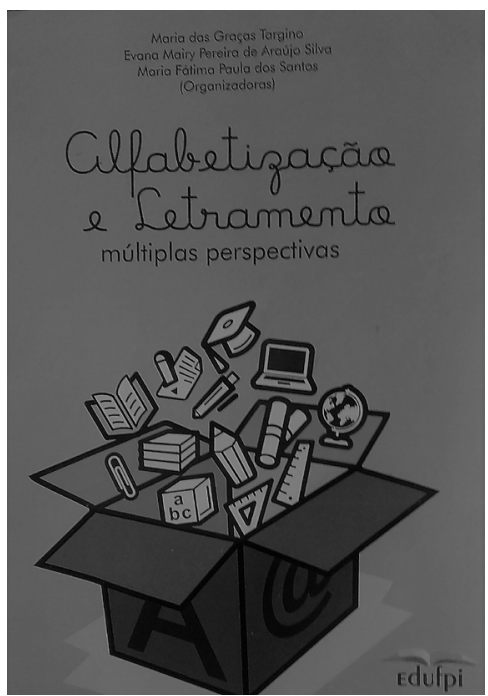
professora Maria das Graças Targino, que já coordenou grupo de pesquisa nos congressos nacionais da Intercom, revela - com certa nostalgia - seu prazer em organizar os textos dessa edição: “Ao organizar com duas companheiras esta coletânea que aí está retorno à delícia que é sentir o lápis deslizando no papel, as rasuras, o apaga-reescreve. Invade-me a certeza de que rabiscar à mão supera o encantamento de mexer nas teclas [...]” (TARGINO; SILVA; SANTOS, 2017).

O livro reúne textos oriundos do curso de Especialização em Alfabetização e Letramento, mantido pelo Centro de Educação Aberto a Distância (CEA)/Universidade Aberta do Brasil (UAB) e Universidade Federal do Piauí. Um belo prefácio, bilíngue, realizado pelo presidente da Associação de Linguistas de Cuba e Ex-Diretor de Pós-Graduação do Ministério de Educação Superior daquele país, Osvaldo Nilo Balmaseda Neyra, dá uma boa contribuição histórica da temática comunicação-educação na América Latina. O também professor da Faculdade de Artes e Letras da Universidade de Havana conta resumidamente como Cuba venceu a guerra contra o analfabetismo da década de 1960. 
A temática comunicação já aparece no primeiro capítulo, intitulado "Universo mágico da alfabetização e do letramento”, de autoria de Maria das Graças Targino. Além de explicar os conceitos de alfabetização e letramento, a autora exemplifica com uma matéria publicada em 1996, na Folha de São Paulo, a importância da alfabetização para a população brasileira. A falta dela (alfabetização) foi causa de impugnação de 20 candidatos de 80 aspirantes a prefeito e vereador em cidades do Estado de São Paulo. Targino (2017) explica que letramento (deriva de literacy) “indica a condição de ser letrado, ou seja, educado e, em especial, que mantém habilidades de ler e escrever” (p.36).

Outros capítulos trazem no seu desenrolar o elemento comunicação perpassando as diversas formas de letramento propostas pelos autores, imbricados com o objeto educação como foco. Os títulos dos capítulos já indicam as temáticas abordadas: Escola e família: aproximação necessária; Literatura fantástica como suporte para o ensino da língua materna; Letramento e poesia: caminho para a formação do leitor; Cantigas de roda na alfabetização e no letramento de crianças; Preconceito linguístico na escola: causas e consequências; Brinquedoteca como espaço de alfabetizar letrando; Educação de jovens e adultos; Tecnologias de informação e comunicação e educação de jovens e adultos; Letramento digital na educação de jovens e adultos e Pichação como prática multiletrada no meio social: direito social pela abordagem sociointeracionista.

Como não haveria espaço suficiente nesta resenha para esmiuçar cada um dos capítulos da coletânea, destacamos o capítulo nove, de Illuska Silva Ferreira e Maria Juracema Silva Ferreira, que aborda as tecnologias de informação e de comunicação em educação de jovens e adultos. Segundo as autoras: "Dentre os sérios desafios da prática docente está tanto a forma de ensinar quanto os recursos ora utilizados, o que incorpora o fato de a escola não ter ou não saber lidar com as TIC” (FERREIRA; FERREIRA, 2017, p.177). Para as autoras, “os recursos computacionais por si só não desempenham as funções esperadas se não forem mediados por professores capacitados” (FERREIRA; FERREIRA, 2017, p.179). Ferreira \& Ferreira (2017) alertam que o risco de desatualização atinge em cheio os docentes quando o assunto é as novas tecnologias. Para elas, a capacitação do docente é essencial.

O capítulo dez, de Ivanete Lustosa, Luciana de Lima e Sebastiana Dalva Valentim Martins, todas pedagogas, lança luzes sobre o letramento digital de jovens e adultos. Para as autoras, "é indiscutível a relevância do letramento digital ou eletrônico para a inclusão social e a democratização do conhecimento” (LUSTOSA; LIMA; MARTINS, 2017, p.187) e defendem a inclusão digital como meio democrático de acesso ao conhecimento:

Inclusão digital ou infoinclusão é a democratização de acesso às TIC de forma a permitir a inserção do indivíduo no mundo digital com a capacidade de responder adequadamente às demandas sociais que envolvem a utilização dos recursos tecnológicos: assim sendo, uma pessoa incluída digitalmente 
não é aquela que usa exclusivamente as novas linguagens do mundo digital, mas é aquela que usa exclusivamente as novas linguagens do mundo digital, mas é quem desfruta de tal capacidade para melhorar sua qualidade de vida (LUSTOSA; LIMA; MARTINS, 2017, p.182).

Dessa forma, o livro “Alfabetização e Letramento: múltiplas perspectivas” vale para os comunicadores que estudam em áreas que permeiam a educação e novas tecnologias, obtendo novos olhares sobre seus objetos de pesquisa. Por vezes, uma coletânea como essa faz justamente aquilo que precisamos para inovar: deslocar nossos olhares da comunicação de foco principal para um segundo plano, vendo de uma nova angulação, novo prisma, novo foco.

\section{Referências}

FERREIRA, I. S.; FERREIRA, M. J. S. Tecnologias de informação e de comunicação e educação de jovens e adultos. In: TARGINO, M. G.; SILVA, E. M. P.; SANTOS, M. F. P. (Orgs.). Alfabetização e Letramento: múltiplas perspectivas. Teresina: EDUFPI, 2017, p.158-174.

LUSTOSA, I.; LIMA, L.; MARTINS, S. D. V. Letramento digital na educação de jovens e adultos. In: TARGINO, M. G.; SILVA, E. M. P.; SANTOS, M. F. P. (Orgs.). Alfabetização e Letramento: múltiplas perspectivas. Teresina: EDUFPI, 2017, p.175-190.

TARGINO, M. G. Universo mágico da alfabetização e do letramento. In: TARGINO, M. G.; SILVA, E. M. P.; SANTOS, M. F. P. (Orgs.). Alfabetização e Letramento: múltiplas perspectivas. Teresina: EDUFPI, 2017, p.27-41.

TARGINO, M. G.; SILVA, E. M. P.; SANTOS, M. F. P. [Orelha do livro]. In: TARGINO, M. G.; SILVA, E. M. P.; SANTOS, M. F. P. (Orgs.).. Alfabetização e Letramento: múltiplas perspectivas. Teresina: EDUFPI, 2017.

TARGINO, M. G.; SILVA, E. M. P.; SANTOS, M. F. P. (Orgs.). Alfabetização e Letramento: múltiplas perspectivas. Teresina: EDUFPI, 2017.

\section{Arquimedes Pessoni}

Graduado em Comunicação Social - Jornalismo pela Universidade Metodista de São Paulo (Umesp), mestre e doutor em Comunicação Social pela Universidade Metodista de São Paulo (Umesp), pósdoutorado na Faculdade de Medicina do ABC (Santo André-SP). Docente titular dos programas de Mestrado Profissional de Comunicação e de Ensino em Saúde na Universidade Municipal de São Caetano do Sul (USCS-SP). E-mail: pessoni@uscs.edu.br.

Recebido em: 15.01 .2018

Aceito em: 29.10.2018

Este artigo é publicado em acesso aberto (Open Access) sob a licença Creative Commons Attribution Non-Commercial (CC-BY-NC), que permite uso, distribuição e reprodução em qualquer meio, sem restrições, desde que sem fins comerciais e que o trabalho original seja corretamente citado.

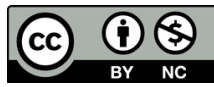

